\title{
Complementary Performance of Organoselenides and Organotellurides as Antimicrobials Agents
}

\author{
Felipe G. Borges, ${ }^{a}$ Tay Zugman, ${ }^{a}$ Pamela T. Bandeira, ${ }^{a}$ Mara C. Dalmolin, ${ }^{a}$ \\ Débora B. Scariot, ${ }^{b}$ Francielle P. Garcia, ${ }^{b}$ Alfredo R. M. de Oliveira, ${ }^{a}$ \\ Celso V. Nakamura ${ }^{b}$ and Leandro Piovan ${ }^{\circledR} *, a$
}

\begin{abstract}
${ }^{a}$ Laboratório de Síntese Química e Enzimática (LaSQuE), Departamento de Química, Universidade Federal do Paraná, 81531-980 Curitiba-PR, Brazil
\end{abstract}

${ }^{b}$ Laboratório de Inovação Tecnológica no Desenvolvimento de Fármacos e Cosméticos Health Sciences Center, Universidade Estadual de Maringá, 87020-900 Maringá-PR, Brazil

\begin{abstract}
Fungi and bacteria are well-known pathogens for plants, fruits, and animals, including humans. In this context, the prospection of antimicrobial agents is crucial to provide new alternatives for the treatment of microbial diseases. Hence, selenium- and tellurium-containing compounds are underexploited and herein, antimicrobial activity of several organochalcogenated compounds was evaluated against Gram-negative and Gram-positive bacteria and fungi. A direct comparison between Se- and Te-containing compounds was performed, as well as structure-activity relationship studies. Among assayed compounds, secondary Se-amines LQ16 and LQ20 and secondary Te-amine LQ28 showed excellent results against a variety of fungi, while primary Te-amine LQ10 demonstrated promising results against bacteria. These results suggest organoselenides and organotellurides may be used for the development of new antimicrobial agents.
\end{abstract}

Keywords: organochalcogenides, biological activity, fungi, bacteria, chalcogen amines, chalcogen ketones

\section{Introduction}

Infectious diseases and food contamination ${ }^{1,2}$ caused by bacteria and fungi represent a health risk for plants and animals, ${ }^{3}$ including humans. ${ }^{4}$ Indeed, some microorganisms have developed resistance to existing antimicrobial agents, ${ }^{5}$ mainly due to the indiscriminate use of antimicrobial drugs in human, veterinary, and agricultural applications. ${ }^{6}$ Resistance may be caused by intrinsic factors (structural or functional characteristics) or due to a mutation (changing the target site, enzymatic resistance, and efflux pumps), ${ }^{7}$ hindering combat and treatment.

Bacteria are especially challenging, ${ }^{8}$ such as Grampositive bacteria Staphylococcus aureus, which can cause skin, lung, and heart infections ${ }^{9}$ and presents a great capacity to develop antibiotic resistance. ${ }^{10}$ In the same way, Gram-negative bacteria Pseudomonas aeruginosa, an opportunistic pathogen, is involved in serious respiratory infections in humans. ${ }^{11}$ Additionally, Gram-negative bacteria Escherichia coli, also used as an indicator of drug

*e-mail: 1piovan@quimica.ufpr.br resistance in bacterial communities due to its gene coding reservoir, presents remarkably diverse pathogenic forms, ranging from enteric diseases to extra-intestinal infections, such as urinary tract or systemic problems. ${ }^{12}$

Pathogenic fungi are also responsible for billions of infections annually, with ca. 1 million attributable mortalities. ${ }^{13}$ The yeasts of Candida genus cause mainly opportunistic infections in immunocompromised patients. ${ }^{14}$ Trichophyton and Microsporum genus are also important infectious disease prompters among dermatophyte fungi, being the major cause of superficial mycoses and also an important public health problem, with Trichophyton rubrum as one of the most prevalent species. ${ }^{15}$

In this context, there is a room for discovering new antimicrobial compounds either from natural sources ${ }^{16}$ or through the development of synthetic compounds such as selenium- and tellurium-containing ones. ${ }^{17}$ Thus, the insertion of selenium and tellurium in organic structure allows to achieve a broad diversity of substances according to the oxidation state of chalcogen. This range of possibilities could imply in substances with distinct biological activity. Organochalcogenated substances have 
already been described as antioxidant, ${ }^{18}$ anticancer, ${ }^{19}$ cysteine- ${ }^{20}$ and threonine-proteases ${ }^{21}$ and tyrosine phosphatase inhibitors, ${ }^{22}$ antidepressant, ${ }^{23}$ neuroprotector, ${ }^{24}$ antiviral, ${ }^{25}$ antinociceptive, ${ }^{26,27}$ anticonvulsant, ${ }^{28}$ and antiinflammatory. ${ }^{26,29}$ On the other hand, the antimicrobial activity of organochalcogenated compounds has been scarcely exploited.

To the best of our knowledge, selenides have been reported as active against bacteria such as Gram-negative Escherichia coli, ${ }^{30-34}$ Pseudomonas aeruginosa, ${ }^{30,34}$ Salmonella typhimurium, ${ }^{1,30}$ Salmonella enteritidis ${ }^{2,33}$ among others, ${ }^{33,34}$ and Gram-positive Listeria monocytogenes, ${ }^{1,2,30,31,35}$ Staphylococcus aureus, , 1,2,30,33,34,36 Bacillus cereus, ${ }^{30,33-36}$ Enterococcus faecalis ${ }^{31}$ among others. ${ }^{35}$ Tellurides antibacterial activity are scarce and only Escherichia coli, ${ }^{37,38}$ Klebsiella pneumonia, ${ }^{37}$ Salmonella spp. ${ }^{37}$ (Gram-negatives), Staphylococcus aureus, ${ }^{37}$ Streptococcus sp., ${ }^{37}$ Bacillus subtilis, ${ }^{37}$ and Bacillus cereus ${ }^{37}$ (Gram-positives) were assayed.

Regarding antifungal activities, selenides have been reported as active against Candida species $^{31-33,36}$ (C. albicans, C. keyfer, C. krusei, and C. parapsilosis), Cryptococcus neoformans, ${ }^{31}$ Chrysosporium tropicum, ${ }^{36}$ Aspergillus niger, ${ }^{31-33}$ Neurospora crassa, ${ }^{31}$ Aspergillus fumigatus, ${ }^{32}$ and Trichophyton rubrum. ${ }^{36}$ For tellurides, once again a small number of microorganisms have been assayed and only Aspergillus spp., ${ }^{37}$ Candida spp., ${ }^{37}$ and fluconazole-resistant Candida albicans ${ }^{39}$ strains were reported.

It is also worth mentioning the absence of direct comparative studies between selenium and telluriumcontaining congeners in literature. Due to this fact, we decided to carry out this study involving organoselenides and organotellurides to compare their antimicrobial activities against Gram-negative and Gram-positive bacteria and fungi. Ortho, meta, and para-substituted organochalcogen ketones and amines (primary and secondary) were evaluated and structure-activity relationships were identified.

\section{Results and Discussion}

\section{Synthesis of compounds}

To evaluate and compare the antimicrobial activity of Se- and Te-containing compounds, a series of organochalcogenides was synthesized. The effects of structural changes, such as chalcogen atom ( $\mathrm{Se}$ or $\mathrm{Te}$ ), aromatic ring substitution pattern (ortho, meta, and para), and the presence of a second functional group (ketone or amine) were evaluated. All substances were prepared as previously reported by our group. ${ }^{40}$ Briefly, organoselenium ketones LQ13-15 were prepared from the reaction of aryl diazonium salts of ortho, meta, and para-amino acetophenones with lithium butylselenolate at $0{ }^{\circ} \mathrm{C}$ (Scheme 1) with 38-57\% yield (Table 1). Se-ketones LQ14-15 were obtained in the form of orange oils, except the ortho congener LQ13, which showed up as a yellow solid.

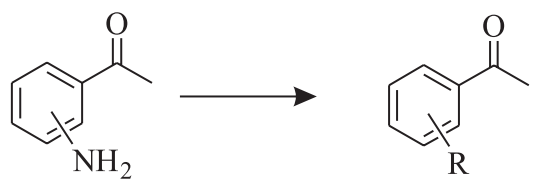

LQ13-15

Scheme 1. Reagents and conditions: (i) $\mathrm{H}_{2} \mathrm{SO}_{4}, \mathrm{H}_{2} \mathrm{O}, \mathrm{NaNO}_{2}$; (ii) $\mathrm{Na}_{2} \mathrm{CO}_{3(\text { aq }}, \mathrm{pH} 7$; (iii) BuSeLi, room temperature, $1 \mathrm{~h}$.

Table 1. Yields for the synthesis of Se-ketones LQ13-15

\begin{tabular}{lcc}
\hline Organochalcogenide & $\mathrm{R}$ & Yield / \% \\
\hline LQ13 & $o \mathrm{Se}^{\mathrm{n}} \mathrm{Bu}$ & 55 \\
LQ14 & $m \mathrm{Se}^{\mathrm{n}} \mathrm{Bu}$ & 38 \\
LQ15 & $p \mathrm{Se}^{\mathrm{n}} \mathrm{Bu}$ & 57 \\
\hline
\end{tabular}

Organotellurium ketones LQ45-46 were synthesized as yellowish oils from the reaction of corresponding diacetal ditellurides with $\mathrm{NaBH}_{4}(\mathrm{Te}-\mathrm{Te}$ bond cleavage) followed by Te-alkylation with butyl bromide. In the sequence, acetal deprotection reaction with $p$ TSA in acetone led to Te-ketones LQ45-46 (Scheme 2) with 57-73\% isolated yield (Table 2).

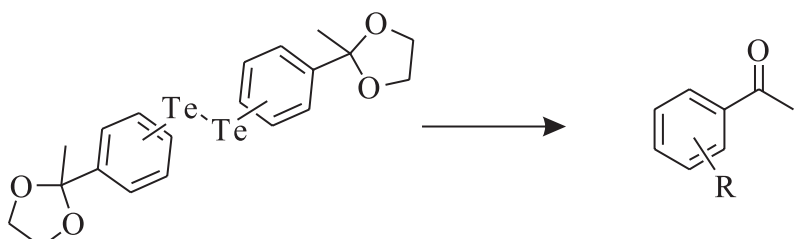

LQ45-46

Scheme 2. Reagents and conditions: (i) ${ }^{\mathrm{n}} \mathrm{BuBr}$, THF, $0{ }^{\circ} \mathrm{C}$; (ii) $\mathrm{NaBH}_{4 \text { (aq)) }}$, $10 \mathrm{~min}$; (iii) acetone, $p$ TSA, $3 \mathrm{~h}$.

Table 2. Yields for the synthesis of Te-ketones LQ45-46

\begin{tabular}{lcc}
\hline Organochalcogenide & $\mathrm{R}$ & Yield / \% \\
\hline $\mathbf{L Q 4 5}$ & $m \mathrm{Te}^{\mathrm{n}} \mathrm{Bu}$ & 73 \\
LQ46 & $p \mathrm{Te}^{\mathrm{n}} \mathrm{Bu}$ & 57 \\
\hline
\end{tabular}

Finally, organochalcogen amines (LQ9-10, LQ16-18, LQ20, LQ28, and LQ30) were obtained through reductive amination, from the corresponding organochalcogen ketone, in a microwave-assisted reaction with a total reaction time of $5 \mathrm{~min}$ (Scheme 3), in a $43-89 \%$ yield 
(Table 3). Se-amines LQ16-18, LQ20, and LQ30 were obtained as yellow liquids, while Te-amines LQ09-10 were obtained as yellow oils and $\mathbf{L Q 2 8}$ was obtained as an orange oil.

All substances were characterized by ${ }^{1} \mathrm{H}$ and ${ }^{13} \mathrm{C}$ nuclear magnetic resonance (NMR), Fourier-transform infrared spectroscopy (FTIR), and gas chromatography-mass

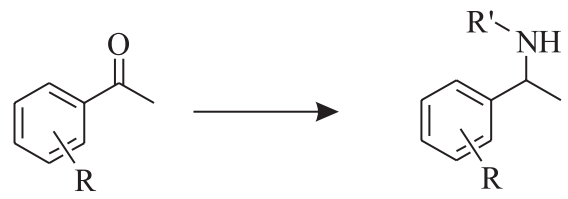

LQ09-10,16-18,20,28,30

Scheme 3. Reagents and conditions: $\mathrm{EtOH}$, amine source, $\mathrm{NaBH}_{3} \mathrm{CN}$, AcOH, microwave, $80^{\circ} \mathrm{C}, 5 \mathrm{~min}$.

Table 3. Yields for the synthesis of chalcogen amines

\begin{tabular}{lccc}
\hline Organochalcogenide & $\mathrm{R}$ & $\mathrm{R}^{\prime}$ & Yield / \% \\
\hline LQ09 & $m \mathrm{Te}^{\mathrm{n}} \mathrm{Bu}$ & $\mathrm{H}$ & 89 \\
LQ10 & $p \mathrm{Te}^{\mathrm{B}} \mathrm{Bu}$ & $\mathrm{H}$ & 73 \\
LQ30 & $o \mathrm{Se}^{\mathrm{n}} \mathrm{Bu}$ & $\mathrm{H}$ & 67 \\
LQ17 & $m \mathrm{Se}^{\mathrm{n}} \mathrm{Bu}$ & $\mathrm{H}$ & 51 \\
LQ18 & $p \mathrm{Se}^{\mathrm{n}} \mathrm{Bu}$ & $\mathrm{H}$ & 43 \\
LQ16 & $p \mathrm{Se}^{\mathrm{n}} \mathrm{Bu}$ & $s-\mathrm{Bu}$ & 56 \\
LQ20 & $p \mathrm{Se}^{\mathrm{n}} \mathrm{Bu}$ & $i$-Bu & 40 \\
LQ28 & $p \mathrm{Te}^{\mathrm{n}} \mathrm{Bu}$ & $i$-Bu & 86 \\
\hline
\end{tabular}

spectrometry (GC-MS) and their data are in accordance with the literature. ${ }^{40}$

\section{Biological assays}

After the synthesis, all organochalcogenides were assayed against the bacteria Staphylococcus aureus ATCC 25923 (Gram-positive), Escherichia coli ATCC 25922 (Gram-negative), Pseudomonas aeruginosa ATCC 27853 (Gram-negative); the yeasts Candida parapsilosis ATCC 22019, Candida tropicalis ATCC 200958, Candida krusei ATCC 6258, Candida albicans ATCC 10231; and against dermatophyte fungi Trichophyton rubrum ATCC 28189, Trichophyton mentagrophytes ATCC 11480 , and Microsporum gypseum ATCC 14683. The results, expressed as MIC (minimum inhibitory concentration), MBC (minimum bactericidal concentration), and MFC

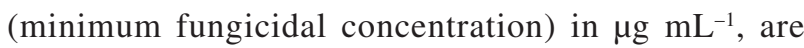
compilated in Tables 4 and 5. For the analysis of the results, the antimicrobial activities were considered good for $\mathrm{MIC}<100 \mu \mathrm{g} \mathrm{mL}^{-1}$; moderate to MIC between 100 and $500 \mu \mathrm{g} \mathrm{mL} \mathrm{L}^{-1}$, weak for MIC between 500 and $1000 \mu \mathrm{g} \mathrm{mL}^{-1}$ and inactive if $\mathrm{MIC}>1000 \mu \mathrm{g} \mathrm{mL} \mathrm{m}^{-1}{ }^{41}$

Antibacterial activity

The results presented in Table 4 disclosed the Te-ketone LQ46 $\left(\mathrm{MIC} / \mathrm{MBC}=125 / 1000 \mu \mathrm{g} \mathrm{mL}^{-1}\right)$ and Te-amines

Table 4. Antibacterial activity of the synthesized compounds

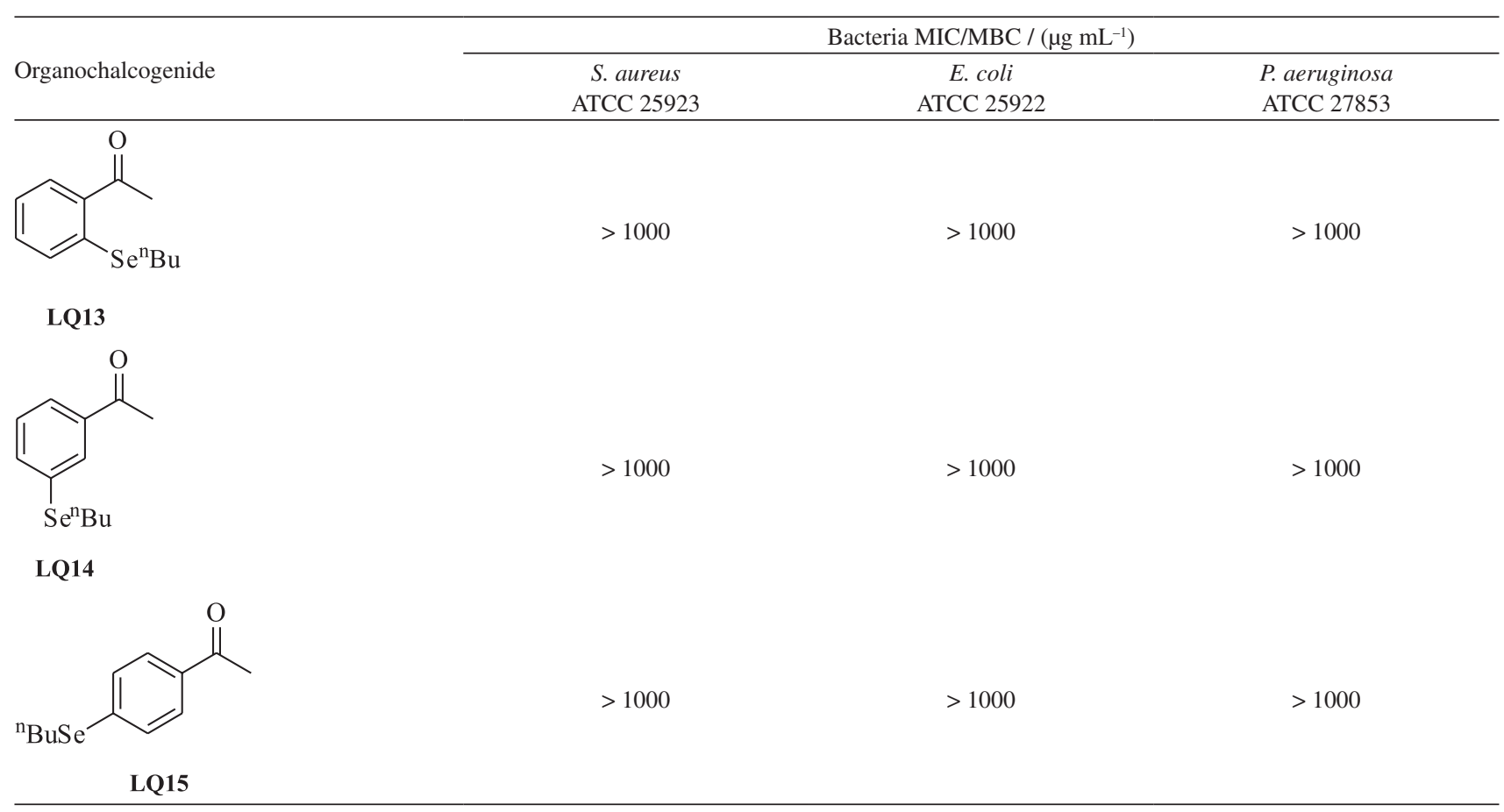


Table 4. Antibacterial activity of the synthesized compounds (cont.)

\begin{tabular}{lccc}
\hline & \multicolumn{3}{c}{ Bacteria MIC/MBC $/\left(\mu \mathrm{g} \mathrm{mL} \mathrm{mL}^{-1}\right)$} \\
\cline { 2 - 4 } Organochalcogenide & S. aureus & E. coli & P. aeruginosa \\
& ATCC 25923 & ATCC 25922 & ATCC 27853 \\
\hline
\end{tabular}<smiles>CC(=O)c1cccc(C(C)(C)C)c1</smiles>

$500 / 1000 \quad 125 / 250 \quad>1000$

\section{LQ45}<smiles>CC(=O)c1ccc(C(Br)Br)cc1</smiles><smiles>CC(N)c1cccc(C(C)(C)C)c1</smiles>

\section{LQ09}<smiles>CC(N)c1ccc(C(Br)(Br)Br)cc1</smiles><smiles>CC(N)c1ccccc1Br</smiles>

LQ30<smiles>CC(N)c1cccc(SCC(C)(C)C)c1</smiles>

LQ17<smiles>CC(N)c1ccc(C(C)(C)C)cc1</smiles><smiles>CCC(C)NC(C)c1ccc(C(C)(C)C)cc1</smiles> 
Table 4. Antibacterial activity of the synthesized compounds (cont.)

Bacteria MIC/MBC / $\left(\mu \mathrm{g} \mathrm{mL}^{-1}\right)$
$\begin{gathered}\text { S. aureus } \\ \text { ATCC } 25923\end{gathered}$

MIC: minimal inhibitory concentration; MBC: minimal bactericidal concentration.

Table 5. Antifungal activity of the synthesized compounds

\begin{tabular}{|c|c|c|c|c|c|c|c|}
\hline \multirow[b]{2}{*}{ Compound } & \multicolumn{7}{|c|}{ Fungi MIC/MFC / $\left(\mu \mathrm{g} \mathrm{mL}^{-1}\right)$} \\
\hline & $\begin{array}{c}\text { T. rubrum } \\
\text { ATCC } 28189\end{array}$ & $\begin{array}{l}\text { T. mentagrophytes } \\
\text { ATCC } 11480\end{array}$ & $\begin{array}{l}\text { M. gypseum } \\
\text { ATCC } 14683\end{array}$ & $\begin{array}{c}\text { C. parapsilosis } \\
\text { ATCC } 22019\end{array}$ & $\begin{array}{c}\text { C. tropicalis } \\
\text { ATCC } 200958\end{array}$ & $\begin{array}{c}\text { C. krusei } \\
\text { ATCC } 6258\end{array}$ & $\begin{array}{r}\text { C. albicans } \\
\text { ATCC } 1023\end{array}$ \\
\hline & $1000 / 1000$ & $1000 / 1000$ & $1000 / 1000$ & $>1000$ & $>1000$ & $>1000$ & $>1000$ \\
\hline
\end{tabular}

LQ13

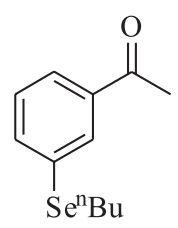

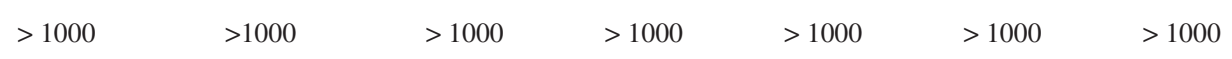

\section{LQ14}<smiles>CCC(C)(C)c1ccc(C(C)=O)cc1</smiles>

LQ15<smiles>CC(=O)c1cccc(Br)c1</smiles>

$250 / 250$

LQ45<smiles>CC(=O)c1ccc(C(Br)(Br)Br)cc1</smiles>

$\begin{array}{llllll}500 / 500 & 500 / 1000 & 1000 / 1000 & >1000 & >1000 & >1000\end{array}$


Table 5. Antifungal activity of the synthesized compounds (cont.)

\begin{tabular}{cccccccc}
\hline & \multicolumn{5}{c}{ Fungi MIC/MFC / $\left(\mu \mathrm{g} \mathrm{mL} \mathrm{mL}^{-1}\right)$} \\
\cline { 2 - 6 } Compound & T. rubrum & T. mentagrophytes & M. gypseum & C. parapsilosis & C. tropicalis & C. krusei & C. albicans \\
& ATCC 28189 & ATCC 11480 & ATCC 14683 & ATCC 22019 & ATCC 200958 & ATCC 6258 & ATCC 10231
\end{tabular}<smiles>CC(N)c1cccc(C(C)(C)C)c1</smiles>
ATCC $28189 \quad$ ATCC 11480

$500 / 500$

$500 />1000$

$500 / 500$

$1000 / 1000$

$500 / 1000$

$500 / 1000$

$1000 />1000$

LQ09<smiles>CC(N)c1ccc(C(Br)(Br)Br)cc1</smiles>

$500 / 500$

$500 / 1000$

$500 / 1000$

$500 / 500$

$500 / 500$

$250 / 1000$

1000/1000<smiles>CC(N)c1ccccc1Br</smiles>

$500 / 1000$

$500 / 1000$

$1000 />1000$

$>1000$

$>1000$

$1000 / 1000$

$1000 / 1000$

LQ30<smiles>CCCCc1cccc(C(C)N)c1</smiles>

1000/1000

$1000 />1000$

$1000 / 1000$

$1000 / 1000$

$1000 />1000$

$1000 / 1000$

$250 / 250$

LQ17<smiles>CC(N)c1ccc(C(C)(C)C)cc1</smiles>

$1000 / 1000 \quad 1000 / 1000 \quad 1000 />1000 \quad 1000 / 1000 \quad>1000 \quad 500 / 1000 \quad 125 / 250$<smiles>CCC(C)NC(C)c1ccc(C(C)CC)cc1</smiles>

$625 / 125$

$62.5 / 125$

$62.5 / 62.5$

$500 / 1000$

$500 / 500$

$250 / 500$

$31.25 / 125$

LQ16<smiles>CC(C)CNC(C)c1ccc(C(C)(C)C)cc1</smiles>

$31.25 / 31.25$

$62.5 / 62.5$

$1000 / 1000$

$500 / 1000$

$500 />1000$

$31.25 / 250$

LQ20<smiles>CC(C)CNC(C)c1ccc(C(C)(C)C)cc1</smiles>

$62.5 / 62.5-125 / 125$

250/500

$250 / 250$

$125 / 250$

$250 / 250$

\section{LQ28}

Fluconazole

$31.25 / 31.25$

$125 / 125$

$125 / 125$

$3.9 / 7.8$

$3.9 / 3.9$

$62.5 / 125$

7.8/7.8 
LQ10 $\left(\mathrm{MIC} / \mathrm{MBC}=250 / 250 \mu \mathrm{g} \mathrm{mL}^{-1}\right)$ and LQ28 $\left(\mathrm{MIC} / \mathrm{MBC}=125 / 250 \mu \mathrm{g} \mathrm{mL} \mathrm{m}^{-1}\right)$ as the most powerful substances against Gram-positive bacteria S. aureus. LQ10 and LQ28 were considered more powerful agents than LQ46 since they were able to cause death of $S$. aureus in a lower concentration. These results highlighted the fact that amine-containing tellurides were more effective than ketone-containing ones.

These Te-amines are both para-substituted, which indicates that this pattern was preponderant for this particular biological activity, especially when LQ10 (MIC $\left.=250 \mu \mathrm{g} \mathrm{mL}^{-1}\right)$ is directly compared with its meta counterpart LQ09 $\left(\mathrm{MIC}=500 \mu \mathrm{g} \mathrm{mL}^{-1}\right.$ ), considered as a weak bactericidal agent for $S$. aureus.

The nature of chalcogen had a strong influence over antibacterial activity against $S$. aureus. This is easily observed by direct comparison of MIC values of LQ20 (secondary Se-amine, MIC $=500 \mu \mathrm{g} \mathrm{mL}^{-1}$ ), LQ28 (secondary Te-amine, $\mathrm{MIC}=125 \mu \mathrm{g} \mathrm{mL}^{-1}$ ), LQ10 (primary Te-amine, MIC $=250 \mu \mathrm{g} \mathrm{mL}^{-1}$ ), and LQ18 (primary Se-amine, $\mathrm{MIC}=1000 \mu \mathrm{g} \mathrm{mL}^{-1}$ ), which demonstrate that the presence of tellurium led to more effective substances than the presence of selenium.

The ketones synthesized in this work followed a similar behavior, since Te-ketones had better antimicrobial activity than Se-ketones against $S$. aureus and, in addition, the compound LQ46 showed better MIC value than Se-amines, which highlights the role of the presence of tellurium in the structure. However, MIC/MBC values of the two secondary Se-amines LQ16 and LQ20 $\left(\mathrm{MIC} / \mathrm{MBC}=500 / 500 \mu \mathrm{g} \mathrm{mL}^{-1}\right.$ for both) were better than Te-ketones $\left(\mathbf{L Q 4 5}, \mathrm{MIC} / \mathrm{MBC}=500 / 1000 \mu \mathrm{g} \mathrm{mL}^{-1} ; \mathbf{L Q 4 6}\right.$, $\mathrm{MIC} / \mathrm{MBC}=125 / 1000 \mu \mathrm{g} \mathrm{mL}^{-1}$ ), especially through the MBC values, highlighting the relevance of the secondary amine in the structure for this biological activity.

Resembling conclusions can be drawn by comparing tellurium and selenium compounds against Gram-negative E. coli and $P$. aeruginosa bacteria, since tellurium compounds presented preeminent antibacterial activity than their selenylated equivalents. This can be seen through the results of the primary Te-amine LQ10, which presented the highest activity against the two Gram-negative bacteria tested, with MIC/MBC values of $62.5 / 62.5$ and $62.5 / 250 \mu \mathrm{g} \mathrm{mL}^{-1}$ against E. coli and $P$. aeruginosa, respectively. Primary Te-amine (LQ09) showed moderate activities $\left(\mathrm{MIC} / \mathrm{MBC}=125 / 125 \mu \mathrm{g} \mathrm{mL}^{-1}\right)$ for both $E$. coli and P. aeruginosa bacteria. All primary Se-amines (LQ17, LQ18, and LQ30) activities were considered no significant. Secondary Te-amine (LQ28), presented moderate activity against $E$. coli $\left(\mathrm{MIC} / \mathrm{MBC}=125 / 125 \mu \mathrm{g} \mathrm{mL}^{-1}\right)$ and weak activity against $P$. aeruginosa $\left(\mathrm{MIC} / \mathrm{MBC}=500 />1000 \mu \mathrm{g} \mathrm{mL}^{-1}\right)$, which suggests that the primary amine is preferred to the secondary one for $P$. aeruginosa, not being an evident phenomenon to the $S$. aureus. Secondary Se-amines (LQ16 and LQ20) exhibited no significant activities, showing again that tellurium compounds were better than selenium for these two bacteria. Against $E$. coli, Te-ketones LQ45 and LQ46 exhibited weak and moderate activity, respectively, suggesting that the amine functional group led to more active compounds than ketone-containing congeners. Furthermore, the selenylated ketones (LQ13, LQ14, and LQ15) were not considered to be significantly active for these bacteria.

\section{Antifungal activity}

In the evaluation of organochalcogenides against fungi (Table 5), the ones with secondary amines were the most powerful antifungal agents, as observed for T. mentagrophytes and M. gypseum fungi. For T. mentagrophytes, MIC/MFC of the secondary chalcogen amines LQ16, LQ20, and LQ28 were 62.5/125, 31.25/31.25, and 62.5/62.5 $\mu \mathrm{g} \mathrm{mL}^{-1}$, respectively, these compounds being even more powerful than fluconazole, a reference drug used as control $\left(\mathrm{MIC} / \mathrm{MFC}=125 / 125 \mu \mathrm{g} \mathrm{mL} \mathrm{L}^{-1}\right)$. Secondary Se-amine LQ20 was more efficient than equivalent secondary Te-amine LQ28. Similar results were observed in assays with $M$. gypseum, in which secondary Se-amines LQ16 (MIC/MFC $=62.5 / 62.5 \mu \mathrm{g} \mathrm{mL}^{-1}$ ) and LQ20

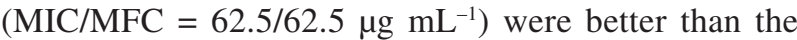
control. For secondary Te-amine LQ28, MIC/MFC values were equal to fluconazole.

Evaluation against $T$. rubrum presented similar results for the following compounds: LQ16 $\left(\mathrm{MIC} / \mathrm{MFC}=62.5 / 125 \mu \mathrm{g} \mathrm{mL} \mathrm{mL}^{-1}\right), \quad \mathbf{L Q 2 0}$

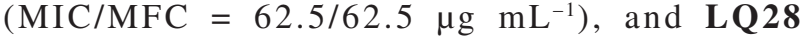
(MIC/MFC $=62.5 / 62.5 \mu \mathrm{g} \mathrm{mL}^{-1}$ ), where it was observed that a change in the position of methyl substituent leads to a tenuous difference in MFC, beneficial for $\mathbf{L Q 2 0}$ isomer, while the nature of chalcogen did not influence in this case. Antifungal activities of primary organochalcogen amines (LQ09, LQ10, LQ17, LQ18, and LQ30) were considered weak or no significant for all the tested fungi, except for C. albicans. Te-amines performed better as antifungal agents than their respective selenylated equivalents, exception again for the occurrence of $C$. albicans, in which Se-amines LQ17 and LQ18 achieved better outcomes.

Organochalcogen ketones (LQ13, LQ14, LQ15, LQ45, and LQ46) assayed against T. mentagrophytes and $M$. gypseum, presented weak or no significant activities, except for LQ46 against $M$. gypseum, which showed moderate activity $\left(\mathrm{MIC} / \mathrm{MFC}=250 / 250 \mu \mathrm{g} \mathrm{mL}^{-1}\right.$ ). As well as in primary organochalcogen amines, the presence of 
tellurium improved the biological activity in comparison to selenium. A similar conclusion was reached concerning the activities of these same ketones against T. rubrum. It was observed that both Te-ketones (LQ45 and LQ46) showed moderate activity while Se-ketones LQ13 and LQ14 showed no significant activities and just a weak activity was observed for LQ15. For most of the Se-ketones, results were not significant or worse than Te-ketones. Therefore, for the ketones assayed in this work, it can be concluded that tellurium-containing ones were more active than selenium-containing congeners for both fungi and bacteria.

Another obtained conclusion was that para substitution pattern led to more active substances than meta or ortho substitution pattern against T. rubrum. This can be observed by comparing Te-ketones LQ45 (MIC/MFC $=250 / 250 \mu \mathrm{g} \mathrm{mL}^{-1}$ ) and LQ46 (MIC/MFC $=125 / 125 \mu \mathrm{g} \mathrm{mL}^{-1}$ ). This also occurred for Se-ketones LQ13 (MIC/MFC $=1000 / 1000 \mu \mathrm{g} \mathrm{mL}{ }^{-1}$ ), LQ14 ( MIC > $1000 \mu \mathrm{g} \mathrm{mL}^{-1}$ ), and LQ15

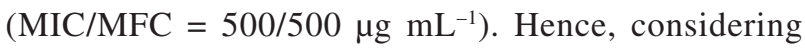
the results for these two fungi, T. mentagrophytes and M. gypseum, it can be said that the secondary amine strongly indulges the biological activity studied in this work, when compared to the primary amine or the ketone function.

Regarding Candida strains, the activity of secondary Te-amine LQ28 was considered moderate for all four species and better than their respective selenylated equivalents, except for $C$. albicans. In this specific case, secondary Se-amines LQ16 $\left(\mathrm{MIC}=31.25 \mu \mathrm{g} \mathrm{mL}^{-1}\right.$ ) and LQ20 ( $\mathrm{MIC}=31.25 \mu \mathrm{g} \mathrm{mL}^{-1}$ ) activities were considered as good, being better than $\mathbf{L Q 2 8}$ ( $\mathrm{MIC}=250 \mu \mathrm{g} \mathrm{mL}^{-1}$ ), which suggests that selenium is preferred over tellurium for $C$. albicans. Similar performance was observed for primary amines, since primary Se-amines LQ17 $\left(\mathrm{MIC}=250 \mu \mathrm{g} \mathrm{mL}^{-1}\right)$

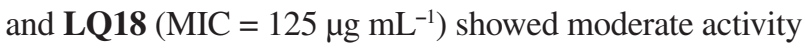
against C. albicans while similar primary Te-amines (LQ09 and LQ10) showed no significant activity. Once more, selenium-containing substances were more powerful than tellurium-containing ones for $C$. albicans. Moreover, for primary Se-amines it can be observed that para position (LQ18) was more active in comparison with meta (LQ17) and ortho (LQ30). Organochalcogen ketones showed no significant activity in most of the cases for Candida strains. The results for T. mentagrophytes and M. gypseum, along with results for Candida strains led to the conclusion that the presence of secondary amine improves the antifungal activity when compared to the primary amine or the ketone function.

\section{Conclusions}

Evaluation of the antimicrobial activity of organochalcogenated ketones and amine disclosed organoselenides as preferential antifungal agents while organotellurides were identified as better antibacterial agents. Organochalcogen ketones were considered inactive. Only primary organotellurium amine LQ10 showed significant antibacterial activity against $E$. coli and $P$. aeruginosa, but it was inactive against fungi. Secondary organoselenium amines LQ16 and LQ20 showed good antifungal activity, mainly against $T$. mentagrophytes and M. gypseum, being even more active than fluconazole. Secondary Te-amine LQ28 was the unique substance that presented moderate antibacterial activity (S. aureus and E. coli) and moderate or good antifungal activity for all yeasts and fungi assayed, choosing $\mathbf{L Q 2 8}$ as a promising structure for the development of antimicrobial agents.

\section{Experimental}

\section{General}

${ }^{1} \mathrm{H}$ and ${ }^{13} \mathrm{C}$ NMR analyses were carried out at room temperature with a Bruker AVANCE 200 or AVANCE 400 spectrometer operating at 4.7 or $9.4 \mathrm{~T}$, and observing ${ }^{1} \mathrm{H}$ at 200.13 or $400.26 \mathrm{MHz}$ and ${ }^{13} \mathrm{C}$ at 50.03 or $100.06 \mathrm{MHz}$ respectively. Chemical shifts, expressed in ppm, are related to the tetramethylsilane (TMS) signal at $0.00 \mathrm{ppm}$ used as internal reference. ${ }^{1} \mathrm{H}$ NMR data are reported as follows: chemical shift $(\delta)$, multiplicity ( $\mathrm{s}=$ singlet, $\mathrm{d}=$ doublet, $\mathrm{t}=$ triplet, $\mathrm{q}=$ quartet, $\mathrm{m}=$ multiplet $)$, coupling constant $(\mathrm{Hz})$, and relative intensity (integral). GC-MS spectra were recorded with a Shimadzu QP-2010 Plus apparatus, equipped with an RTX-5 capillary column (30 $\mathrm{m} \times 0.25 \mathrm{~mm} \times 0.25 \mu \mathrm{m}$ film thickness) and operating in ionization mode by electron impact $(70 \mathrm{eV})$. This was coupled to a Shimadzu GC-2010 gas chromatograph operating with a helium flow rate of $1 \mathrm{~mL} \mathrm{~min}^{-1}$ and an injector temperature set to $200{ }^{\circ} \mathrm{C}$. The temperature was programmed to $50{ }^{\circ} \mathrm{C}$ for $1 \mathrm{~min}$, increased at $10{ }^{\circ} \mathrm{C} \mathrm{min} \mathrm{m}^{-1}$ up to $250{ }^{\circ} \mathrm{C}$ and kept at $250{ }^{\circ} \mathrm{C}$ for $10 \mathrm{~min}$. Selenium compounds were analyzed by Fourier-transform infrared spectroscopy (FTIR) with a BOMEM Michelson MB100 spectroscope in the spectral range of $4000-400 \mathrm{~cm}^{-1}$, with 64 and 32 scans for solid and liquid samples respectively, and resolution of $4 \mathrm{~cm}^{-1}$. $\mathrm{KBr}$ pellets were used for the analysis of solids, while liquid samples were deposited on $\mathrm{KBr}$ crystals.

\section{Synthesis of the organoselenium ketones}

To a cooled solution $\left(0^{\circ} \mathrm{C}\right)$ of the appropriate aminoacetophenone $(0.405 \mathrm{~g}, 3 \mathrm{mmol})$ containing sulfuric acid $(0.8 \mathrm{~mL})$ and water $(0.8 \mathrm{~mL}), 1.0 \mathrm{~mL}$ of an aqueous 
solution of sodium nitrite $(0.276 \mathrm{~g}, 4 \mathrm{mmol})$ was added dropwise, followed by slow addition of an aqueous solution of $\mathrm{Na}_{2} \mathrm{CO}_{3}$ until $\mathrm{pH}$ 7. This reaction mixture then received the addition of lithium butylselenolate $(0.288 \mathrm{~g}, 4.5 \mathrm{mmol})$ dissolved in $5 \mathrm{~mL}$ of THF, which gave a biphasic mixture that was continuously stirred at room temperature for $1 \mathrm{~h}$. Afterward, the mixture was diluted with brine $(20 \mathrm{~mL})$ and extracted with ethyl acetate $(5 \times 20 \mathrm{~mL})$. The organic phase was separated, dried over anhydrous magnesium sulfate, and filtered. The solvent was removed under reduced pressure and the crude material was purified by flash chromatography using a mixture of hexanes and ethyl acetate (9:1) as eluent.

\section{1-(2-(Butylselanyl)phenyl)ethanone (LQ13)}

Yield: 55\%; yellow solid; FTIR (KBr) v / $\mathrm{cm}^{-1} 2957$, 2928, 2870, 2123, 1666, 1585, 1454, 1248, 756; ${ }^{1} \mathrm{H}$ NMR (200 $\left.\mathrm{MHz}, \mathrm{CDCl}_{3}, \mathrm{TMS}\right) \delta 7.90\left(\mathrm{dd}, J_{A} 7.8, J_{B} 1.5 \mathrm{~Hz}\right.$, $1 \mathrm{H}), 7.50(\mathrm{~m}, 1 \mathrm{H}), 7.40\left(\mathrm{td}, J_{A} 7.0, J_{B} 1.5 \mathrm{~Hz}, 1 \mathrm{H}\right), 7.24$ $\left(\mathrm{td}, J_{A} 7.0, J_{B} 1.5 \mathrm{~Hz}, 1 \mathrm{H}\right), 2.84(\mathrm{t}, J 7.5 \mathrm{~Hz}, 2 \mathrm{H}), 2.62(\mathrm{~s}$, $3 \mathrm{H}), 1.73(\mathrm{~m}, 2 \mathrm{H}), 1.50(\mathrm{~m}, 2 \mathrm{H}), 0.95$ (t, J $7.3 \mathrm{~Hz}, 3 \mathrm{H})$; ${ }^{13} \mathrm{C}$ NMR $\left(50 \mathrm{MHz}, \mathrm{CDCl}_{3}\right) \delta 198.7,133.1,132.2,131.7$, $128.5,128.3,124.2,30.7,27.5,24.8,23.4,13.6$; GC-MS $(70 \mathrm{eV}), \mathrm{m} / \mathrm{z}$ (relative abundance): $256\left(\mathrm{M}^{+}, 21\right), 241(1)$, 199 (100), 182 (11), 169 (3), 157 (9), 130 (1), 117 (2), 105 (5), 91 (25), 77 (12), 65 (3), 51 (3), 43 (35).

\section{1-(3-(Butylselanyl)phenyl)ethanone (LQ14)}

Yield: 38\%; orange oil; FTIR (KBr) $v / \mathrm{cm}^{-1} 2959$, 2930, 2870, 1944, 1686, 1568, 1464, 1252, 785; ${ }^{1} \mathrm{H}$ NMR $\left(400 \mathrm{MHz}, \mathrm{CDCl}_{3}, \mathrm{TMS}\right) \delta 7.89\left(\mathrm{dd}, J_{A} 7.7, J_{B} 1.2 \mathrm{~Hz}, 1 \mathrm{H}\right)$, $7.48(\mathrm{~d}, J 7.9 \mathrm{~Hz}, 1 \mathrm{H}), 7.39\left(\mathrm{dt}, J_{A} 7.4, J_{B} 1.0 \mathrm{~Hz}, 1 \mathrm{H}\right), 7.23$ $(\mathrm{m}, 1 \mathrm{H}), 2.83(\mathrm{t}, J 7.5 \mathrm{~Hz}, 2 \mathrm{H}), 2.61(\mathrm{~s}, 3 \mathrm{H}), 1.74(\mathrm{~m}, 2 \mathrm{H})$, $1.50(\mathrm{~m}, 2 \mathrm{H}), 0.95$ (t, J 7.3 Hz, 3H); ${ }^{13} \mathrm{C} \mathrm{NMR}(100 \mathrm{MHz}$, $\left.\mathrm{CDCl}_{3}\right) \delta 198.8,138.3,135.5,132.2,131.7,128.4,124.2$, 30.7, 27.5, 24.8, 23.4, 13.7; GC-MS (70 eV), $\mathrm{m} / z$ (relative abundance): $256\left(\mathrm{M}^{+}, 71\right), 252$ (14), 241 (3), 227 (1), 213 (1), 200 (64), 185 (53), 181 (12), 156 (14), 130 (2), 117 (4), 105 (3), 91 (10), 77 (14), 63 (4), 57 (30), 43 (100).

\section{1-(4-(Butylselanyl)phenyl)ethanone (LQ15)}

Yield: 57\%; orange oil; FTIR (KBr) v / cm $\mathrm{cm}^{-1} 2959,2930$, 2872, 1680, 1587, 1464, 1267, 816; ${ }^{1} \mathrm{H}$ NMR (200 MHz, $\left.\mathrm{CDCl}_{3}, \mathrm{TMS}\right) \delta 7.81\left(\mathrm{dt}, J_{A} 8.6, J_{B} 1.9 \mathrm{~Hz}, 2 \mathrm{H}\right), 7.48(\mathrm{dt}$, $\left.J_{A} 8.6, J_{B} 1.9 \mathrm{~Hz}, 2 \mathrm{H}\right), 3.00(\mathrm{t}, J 7.4 \mathrm{~Hz}, 2 \mathrm{H}), 2.57(\mathrm{~s}, 3 \mathrm{H})$, $1.73(\mathrm{~m}, 2 \mathrm{H}), 1.43(\mathrm{~m}, 2 \mathrm{H}), 0.93(\mathrm{t}, J 7.2 \mathrm{~Hz}, 3 \mathrm{H}) ;{ }^{13} \mathrm{C} \mathrm{NMR}$ $\left(50 \mathrm{MHz} \mathrm{CDCl}_{3}\right) \delta 197.3,139.2,134.8,133.1,130.2$, 128.7, 128.3, 31.9, 26.7, 26.4, 23.0, 13.5; GC-MS (70 eV), $\mathrm{m} / \mathrm{z}$ (relative abundance): $256\left(\mathrm{M}^{+}, 86\right), 241$ (18), $200(58)$, 185 (94), 181 (21), 156 (18), 130 (3), 117 (6), 105 (16), 91 (14), 77 (22), 63 (7), 57 (55), 43 (100).

\section{Synthesis of the organotellurium ketone}

The solution of appropriate ditelluride $(1.74 \mathrm{~g}, 3 \mathrm{mmol})$ and butyl bromide ( $9 \mathrm{mmol}, 0.98 \mathrm{~mL})$ in THF $(40 \mathrm{~mL})$ was cooled to $0{ }^{\circ} \mathrm{C}$ and treated slowly with $\mathrm{NaBH}_{4}(15 \mathrm{mmol}$, $0.567 \mathrm{~g})$ dissolved in water $(10 \mathrm{~mL})$. After stirring for $10 \mathrm{~min}$, aqueous $\mathrm{NH}_{4} \mathrm{Cl}$ solution was added $(20 \mathrm{~mL})$, the resulting mixture extracted with dichloromethane $(3 \times 20 \mathrm{~mL})$ and concentrated under reduced pressure. The crude product was dissolved in acetone $(20 \mathrm{~mL})$, $p$-toluenesulfonic acid (0.03 g) was added and the mixture was refluxed for $3 \mathrm{~h}$. Then, acetone was removed under reduced pressure, water $(10 \mathrm{~mL})$ was added and the product extracted with dichloromethane $(3 \times 20 \mathrm{~mL})$. The combined organic phases were dried over anhydrous magnesium sulfate, concentrated and the product was purified by flash chromatography using hexanes and ethyl acetate (9:1) as eluent.

\section{1-(3-(Butyltellanyl)phenyl)ethanone (LQ45)}

Yield: 73\%; pale oil; FTIR (KBr) v / cm ${ }^{-1} 3051,2957$, 2926, 2870, 2862, 1686, 1678, 1560, 1472, 1356, 1254, $1182,1171,1059,959,789,689,652,592,453 ;{ }^{1} \mathrm{H}$ NMR (200 MHz, $\left.\mathrm{CDCl}_{3}, \mathrm{TMS}\right) \delta 8.02(\mathrm{~s}, 1 \mathrm{H}), 7.74-7.93(\mathrm{~m}, 2 \mathrm{H})$, 7.28 (t, J 7.6 Hz, 1H), 2.95 (t, J 7.6 Hz, 2H), 2.59 (s, 3H), 1.79 (quint, $J 8.0 \mathrm{~Hz}, 2 \mathrm{H}), 1.40$ (sext, $J 7.3 \mathrm{~Hz}, 2 \mathrm{H}), 0.90$ (t, $J 7.3 \mathrm{~Hz}, 3 \mathrm{H}) ;{ }^{13} \mathrm{C} \mathrm{NMR}\left(50 \mathrm{MHz}, \mathrm{CDCl}_{3}\right) \delta 197.6,142.4$, $137.7,129.1,127.3,112.4,33.8,26.6,25.0,13.3,8.9$.

\section{1-(4-(Butyltellanyl)phenyl)ethanone (LQ46)}

Yield: 57\%; orange oil; FTIR (KBr) v / cm $\mathrm{cm}^{-1} 3346$, 2957, 2926, 2870, 1682, 1582, 1423, 1391, 1358, 1269, 1182, 1080, 1009, 957, 816, 743, 679, 600, 590, 451; ${ }^{1} \mathrm{H}$ NMR (200 MHz, $\left.\mathrm{CDCl}_{3}, \mathrm{TMS}\right) \delta 7.67-7.78$ (s, 4H), 2.97 (t, J 7.7 Hz, 2H), 2.57 (s, 3H), 1.82 (quint, J 7.7 Hz, 2H), 1.41 (sext, J 7.7 Hz, 3H), 0.91 (t, J 7.3 Hz, 3H); ${ }^{13} \mathrm{C}$ NMR $\left(50 \mathrm{MHz}, \mathrm{CDCl}_{3}\right) \delta 197.7,136.6,135.8,128.5,120.9$, 33.7, 26.4, 25.1, 13.4, 8.7; GC-MS (70 eV), $\mathrm{m} / \mathrm{z}$ (relative abundance): $306\left(\mathrm{M}^{+}, 12\right), 250$ (9), 234 (8), 206 (6), 120 (2), 105 (15), 91 (4), 77 (17), 73 (4), 57 (28), 43 (100).

\section{Synthesis of the organochalcogen amines}

To a microwave vial, the appropriate amine ( 2 equiv.), acetic acid $(0.525 \mathrm{~g}, 8.7 \mathrm{mmol})$ and sodium cyanoborohydride (1.2 equiv.), were added to a solution of organochalcogen ketone $(0.100 \mathrm{~g}, 0.390 \mathrm{mmol})$ in ethanol $(1 \mathrm{~mL})$. The mixture was heated in a Cem Discovery microwave reactor at $80^{\circ} \mathrm{C}$ for 5 or 10 min under magnetic stirring. Then, the solvent was removed under reduced pressure, the crude material was treated with a $2 \mathrm{~mol} \mathrm{~L}^{-1}$ 
sodium hydroxide solution until $\mathrm{pH} 10$ and the product was extracted with dichloromethane $(3 \times 5 \mathrm{~mL})$. The organic portions were combined, dried over anhydrous magnesium sulfate and filtered. The solvent was removed under reduced pressure and the crude material was purified by flash chromatography using a mixture of ethyl acetate and ethanol (9:1) as eluent.

\section{1-(2-(Butylselanyl)phenyl)ethanamine (LQ30)}

Yield: 67\%; yellow liquid; FTIR (KBr) $v / \mathrm{cm}^{-1} 3360$, 3288, 2959, 2928, 2870, 1906, 1591, 1454, 1257, 822; ${ }^{1} \mathrm{H}$ NMR $\left(200 \mathrm{MHz}, \mathrm{CDCl}_{3}, \mathrm{TMS}\right) \delta 7.46(\mathrm{~m}, 2 \mathrm{H}), 7.27$ (m, $1 \mathrm{H}), 7.18\left(\mathrm{dd}, J_{A} 7.4, J_{B} 1.7 \mathrm{~Hz}, 1 \mathrm{H}\right), 4.58(\mathrm{q}, J 6.6 \mathrm{~Hz}, 1 \mathrm{H})$, $2.91(\mathrm{t}, J 7.3 \mathrm{~Hz}, 2 \mathrm{H}), 1.70(\mathrm{~m}, 2 \mathrm{H}), 1.46$ (m, 2H), 1.38 (d, $J 6.6 \mathrm{~Hz}, 3 \mathrm{H}), 0.92$ (t, J 7.3 Hz, 3H); ${ }^{13} \mathrm{C} \mathrm{NMR}(50 \mathrm{MHz}$, $\left.\mathrm{CDCl}_{3}\right) \delta 147.9,131.0,130.6,129.6,129.1,124.0,51.2$, 32.3, 27.5, 25.3, 22.9, 13.6; GC-MS (70 eV), $\mathrm{m} / \mathrm{z}$ (relative abundance): $257\left(\mathrm{M}^{+}, 44\right), 242$ (21), 238 (6), 200 (93), 183 (79), 179 (16), 157 (6), 131 (2), 119 (93), 104 (100), 91 (28), 72 (30), 65 (4), 51 (8), 44 (23).

\section{1-(3-(Butylselanyl)phenyl)ethanamine (LQ17)}

Yield: 51\%; yellow liquid; FTIR (KBr) v / $\mathrm{cm}^{-1} 3360$, 2959, 2928, 2870, 1940, 1688, 1587, 1464, 1454, 1254, $785 ;{ }^{1} \mathrm{H}$ NMR (200 MHz, $\left.\mathrm{CDCl}_{3}, \mathrm{TMS}\right) \delta 7.47$ (s, 1H) 7.34 $\left(\mathrm{dt}, J_{A} 6.4, J_{B} 1.8 \mathrm{~Hz}, 1 \mathrm{H}\right), 7.20(\mathrm{~m}, 2 \mathrm{H}), 4.08(\mathrm{q}, J 6.6 \mathrm{~Hz}$, $1 \mathrm{H}), 2.93$ (t, J 7.5 Hz, 2H), $1.70(\mathrm{~m}, 2 \mathrm{H}), 1.43(\mathrm{~m}, 2 \mathrm{H})$, 1.37 (d, J 6.6 Hz, 3H), $0.91(\mathrm{t}, J 7.3 \mathrm{~Hz}, 3 \mathrm{H}) ;{ }^{13} \mathrm{C}$ NMR $\left(50 \mathrm{MHz}, \mathrm{CDCl}_{3}\right) \delta 148.6,130.9,130.6,129.7,129.1$, 124.1, 51.2, 32.3, 27.6, 25.6, 23.0, 13.6; GC-MS (70 eV), $\mathrm{m} / \mathrm{z}$ (relative abundance): $257\left(\mathrm{M}^{+}, 34\right), 242$ (100), 214 (1), 200 (5), 185 (28), 158 (5), 137 (1), 120 (16), 106 (22), 91 (9), 78 (21), 65 (3), 55 (10), 44 (48).

\section{1-(4-(Butylselanyl)phenyl)ethanamine (LQ18)}

Yield: 43\%; yellow liquid; FTIR (KBr) v / $\mathrm{cm}^{-1} 3354$, 3288, 2959, 2928, 2870, 1906, 1591, 1493, 1454, 1257, 822; ${ }^{1} \mathrm{H}$ NMR (200 MHz, $\left.\mathrm{CDCl}_{3}, \mathrm{TMS}\right) \delta 7.45$ (dt, $J_{A} 8.3$, $\left.J_{B} 1.8 \mathrm{~Hz}, 2 \mathrm{H}\right), 7.23\left(\mathrm{dt}, J_{A} 8.3, J_{B} 1.8 \mathrm{~Hz}, 2 \mathrm{H}\right), 4.08$ (q, $J 6.6 \mathrm{~Hz}, 1 \mathrm{H}), 2.90(\mathrm{t}, J 7.3 \mathrm{~Hz}, 2 \mathrm{H}), 1.77$ (m, 2H), 1.68 $(\mathrm{m}, 2 \mathrm{H}), 1.37(\mathrm{~s}, 3 \mathrm{H}), 0.90(\mathrm{t}, J 7.3 \mathrm{~Hz}, 3 \mathrm{H}) ;{ }^{13} \mathrm{C} \mathrm{NMR}$ $\left(50 \mathrm{MHz}, \mathrm{CDCl}_{3}\right) \delta 146.3,132.7,128.6,126.4,50.9$, 32.2, 27.8, 25.6, 22.9, 13.5; GC-MS (70 eV), $m / z$ (relative abundance): $257\left(\mathrm{M}^{+}, 22\right), 241$ (100), 214 (1), 200 (5), 186 (20), 158 (4), 133 (1), 120 (22), 106 (23), 91 (6), 78 (17), 65 (2), 55 (4), 42 (15).

\section{1-(3-(Butyltellanyl)phenyl)ethanamine (LQ09)}

Yield: 89\%; yellow oil; ${ }^{1} \mathrm{H}$ NMR $\left(200 \mathrm{MHz}, \mathrm{CDCl}_{3}\right.$, TMS) $\delta 7.85(\mathrm{~s}, 1 \mathrm{H}), 7.56(\mathrm{~d}, J 7.3 \mathrm{~Hz}, 1 \mathrm{H}), 7.08-7.26(\mathrm{~m}$, 2H), 4.08 (q, J $6.5 \mathrm{~Hz}, 1 \mathrm{H}), 2.95$ (t, J 7.5 Hz, 3H), 1.72- $1.90(\mathrm{~m}, 2 \mathrm{H}), 1.40(\mathrm{~d}, J 6.5 \mathrm{~Hz}, 4 \mathrm{H}), 1.25-1.53(\mathrm{~m}, 2 \mathrm{H})$, $0.93(\mathrm{t}, J 7.4 \mathrm{~Hz}, 3 \mathrm{H}) ;{ }^{13} \mathrm{C} \mathrm{NMR}\left(50 \mathrm{MHz}, \mathrm{CDCl}_{3}\right) \delta 148.4$, $136.5,129.2,124.9,112.1,51.1,33.9,25.5,25.0,13.4,8.4$.

\section{1-(4-(Butyltellanyl)phenyl)ethanamine (LQ10)}

Yield: 73\%; yellow oil; FTIR (KBr) v $/ \mathrm{cm}^{-1} 3288,3063$, 2959, 2926, 2870, 1655, 1587, 1560, 1487, 1454, 1400, 1375, 1246, 1095, 1011, 887, 920, 700, 540; ${ }^{1} \mathrm{H}$ NMR (200 MHz, $\left.\mathrm{CDCl}_{3}, \mathrm{TMS}\right) \delta$ 7.65-7.69 (dd, $J_{A} 8.2, J_{B} 1.9 \mathrm{~Hz}$, 2H), 7.15-7.19 (dd, $\left.J_{A} 8.2, J_{B} 1.9 \mathrm{~Hz}, 2 \mathrm{H}\right), 4.08$ (q, J $6.6 \mathrm{~Hz}$, 1H), 2.89 ( t, J 7.8 Hz, 2H), 1.80-1.60 (m, 3H), 1.23-1.50 $(\mathrm{m}, 6 \mathrm{H}), 0.90(\mathrm{t}, J 7.3 \mathrm{~Hz}, 3 \mathrm{H}) ;{ }^{13} \mathrm{C} \mathrm{NMR}\left(50 \mathrm{MHz}, \mathrm{CDCl}_{3}\right)$ $\delta$ 147.2, 138.5, 126.6, 109.5, 51.0, 33.9, 25.6, 25.0, 13.4, 8.4; GC-MS (70 eV), $\mathrm{m} / \mathrm{z}$ (relative abundance): $307\left(\mathrm{M}^{+}\right.$, 84), 292 (82), 249 (8), 235 (63), 206 (2), 120 (51), 104 (100), 91 (14), 77 (44), 65 (4), 44 (78), 41 (39).

$N$-(1-(4-(Butylselanyl)phenyl)ethyl)-2-methylpropan1-amine (LQ20)

Yield: 40\%; yellow liquid; FTIR (KBr) v / $\mathrm{cm}^{-1} 3321$, 2957, 2928, 2870, 1466, 1128, 822; ' $\mathrm{H}$ NMR (200 MHz, $\left.\mathrm{CDCl}_{3}, \mathrm{TMS}\right) \delta 7.43\left(\mathrm{dd}, J_{A} 8.3, J_{B} 1.9 \mathrm{~Hz}, 2 \mathrm{H}\right), 7.20$ $\left(\mathrm{dt}, J_{A} 8.1, J_{B} 1.8 \mathrm{~Hz}, 2 \mathrm{H}\right), 3.69$ (q, $\left.J 6.6 \mathrm{~Hz}, 1 \mathrm{H}\right), 2.91$ (t, J 7.2 Hz, 2H), 2.40-2.15 (m, 2H), 1.78-1.55 (m, 3H), 1.53-1.24 (m, 6H), $0.90(\mathrm{t}, J 7.3 \mathrm{~Hz}, 3 \mathrm{H}), 0.88$ (dd, $J_{A} 6.6$, $\left.J_{B} 0.6 \mathrm{~Hz}, 6 \mathrm{H}\right) ;{ }^{13} \mathrm{C} \mathrm{NMR}\left(50 \mathrm{MHz}, \mathrm{CDCl}_{3}\right) \delta 144.8,132.5$, 128.5, 127.3, 58.0, 55.9, 32.3, 28.5, 27.7, 24.4, 22.9, 20.8, 20.6, 13.5; GC-MS (70 eV), $\mathrm{m} / \mathrm{z}$ (relative abundance): 315 (M+, 1), 298 (39), 270 (4), 241 (100), 207 (2), 185 (22), 157 (2), 132 (2), 104 (39), 78 (10), 65 (1), 57 (11), 44 (5).

N-(1-(4-(Butylselanyl)phenyl)ethyl)butan-2-amine (LQ16)

Yield: 56\%; yellow liquid; FTIR (KBr) v / $\mathrm{cm}^{-1} 3319$, 2959, 2928, 2872, 1902, 1485, 1464, 1371, 1014, 824; ${ }^{1} \mathrm{H}$ NMR (200 MHz, $\mathrm{CDCl}_{3}$, TMS) $\delta 7.43\left(\mathrm{dd}, J_{A} 8.2\right.$ and $\left.J_{B} 1.8 \mathrm{~Hz}, 2 \mathrm{H}\right), 7.18\left(\mathrm{dd}, J_{A} 8.1\right.$ and $\left.J_{B} 1.8 \mathrm{~Hz}, 2 \mathrm{H}\right), 3.86$ (m, 1H), 2.90 (t, J $7.3 \mathrm{~Hz}, 2 \mathrm{H}), 2.38(\mathrm{~m}, 1 \mathrm{H}), 1.69$ (m, $2 \mathrm{H}), 1.35(\mathrm{~m}, 7 \mathrm{H}), 0.91(\mathrm{~m}, 9 \mathrm{H}) ;{ }^{13} \mathrm{C} \mathrm{NMR}(50 \mathrm{MHz}$, $\left.\mathrm{CDCl}_{3}\right) \delta 144.8,132.5,128.4,127.2,54.5,51.2,32.3,30.6$, 27.7, 25.0, 24.5, 22.9, 20.6, 19.5, 13.5, 10.4, 9.8; GC-MS (70 eV), $m / z$ (relative abundance): $313\left(\mathbf{M}^{+}, 4\right), 298(37)$, 284 (12), 256 (2), 241 (100), 199 (2), 185 (27), 157 (2), 146 (1), 120 (3), 104 (50), 78 (14), 57 (9), 44 (19).

N-(1-(4-(Butyltellanyl)phenyl)ethyl)-2-methylpropan1-amine (LQ28)

Yield: 86\%; orange oil; FTIR (KBr) v / $\mathrm{cm}^{-1} 3319$, 3063, 2957, 2928, 2870, 2351, 2328, 2174, 1591, 1556, 1481, 1462, 1394, 1180, 1163, 1119, 1011, 822, 723, 554, 467; ${ }^{1} \mathrm{H} \mathrm{NMR}\left(200 \mathrm{MHz}, \mathrm{CDCl}_{3}, \mathrm{TMS}\right) \delta 7.67$ (dd, $J_{A} 8.1$, $\left.J_{B} 1.6 \mathrm{~Hz}, 2 \mathrm{H}\right), 7.20\left(\mathrm{dd}, J_{A} 8.1, J_{B} 1.6 \mathrm{~Hz}, 2 \mathrm{H}\right), 4.85(\mathrm{sl}, \underline{\mathrm{NH}})$, 
$3.84(\mathrm{q}, J 6.7 \mathrm{~Hz}, 1 \mathrm{H}), 2.90(\mathrm{t}, J 7.5 \mathrm{~Hz}, 2 \mathrm{H}), 2.32(\mathrm{~m}, 2 \mathrm{H})$, 1.78 (quint, $J 7.5 \mathrm{~Hz}, 3 \mathrm{H}), 1.44(\mathrm{~d}, J 6.7 \mathrm{~Hz}, 3 \mathrm{H}), 1.37$ (m, $2 \mathrm{H}), 0.89(\mathrm{t}, J 7.2 \mathrm{~Hz}, 3 \mathrm{H}), 0.88(\mathrm{~d}, J 6.6 \mathrm{~Hz}, 6 \mathrm{H}) ;{ }^{13} \mathrm{C} \mathrm{NMR}$ $\left(50 \mathrm{MHz}, \mathrm{CDCl}_{3}\right) \delta 142.5,138.3,127.8,110.8,58.5,55.1$, $33.9,27.7,25.0,23.1,20.7,20.5,13.4,8.4 ;$ GC-MS $(70 \mathrm{eV})$, $\mathrm{m} / \mathrm{z}$ (relative abundance): $363\left(\mathrm{M}^{+}, 12\right), 346(28), 291(100)$, 234 (18), 207 (7), 105 (81), 78 (22), 41 (21).

\section{Biological assays}

\section{Strains and growth conditions}

The tested microorganisms included Staphylococcus aureus ATCC 25923, Escherichia coli ATCC 25922, Pseudomonas aeruginosa ATCC 27853, Candida albicans ATCC 10231, C. parapsilosis ATCC 22019, C. tropicalis ATCC 200958, and C. krusei ATCC 6258. Bacteria were maintained on Mueller Hinton agar and subcultured in Mueller Hinton broth (MHB) at $37{ }^{\circ} \mathrm{C}$ for $24 \mathrm{~h}$ before each experiment. Yeasts were maintained on Sabouraud dextrose agar plates and subcultured at $37{ }^{\circ} \mathrm{C}$ for $24 \mathrm{~h}$ in Sabouraud dextrose broth (SDB) before each experiment, to ensure viability and purity.

\section{Broth microdilution assay for bacteria and yeast}

The minimum inhibitory concentration (MIC) of all samples were determined by microdilution techniques in Mueller Hinton broth for bacteria, ${ }^{42}$ and Rosewell Park Memorial Institute (RPMI) 1640, pH 7.0, plus $0.165 \mathrm{~mol} \mathrm{~L}^{-1}$ 3 -( $N$-morpholino) propane sulfonic acid (MOPS) buffer for yeasts. ${ }^{43}$ Briefly, $100 \mu \mathrm{L}$ of broth were distributed in each well of 96 -well plates. Then $100 \mu \mathrm{L}$ of the compounds were added in the first well (initial concentration $1 \mathrm{mg} \mathrm{mL}^{-1}$ ), proceeding with serial dilution. Inoculates were then prepared in the same medium at a density adjusted to a $0.5 \mathrm{McFarland}$ turbidity standard, which corresponds to $1 \times 10^{8}$ colony-forming unit $(\mathrm{CFU}) \mathrm{mL}^{-1}$ for bacteria and $1-5 \times 10^{6} \mathrm{CFU} \mathrm{mL}^{-1}$ for yeast and then diluted 1:10 (bacteria) or 1:100 (yeast). Finally, $5 \mu \mathrm{L}$ of the inoculum were added in each well of the plate. Positive control (wells without compounds) and negative control (wells without compounds and inoculum) were also performed. In addition, the reference drug streptomycin was also tested concomitantly.

The plates were incubated at $37^{\circ} \mathrm{C}$ and the MIC were recorded after $24 \mathrm{~h}$ of incubation for bacteria and $48 \mathrm{~h}$ for yeast. The MIC was defined as the lowest concentration of compounds at which the microorganism tested did not demonstrate visible growth. For the analysis of the results, the antimicrobial activities were considered good for MIC $<100 \mu \mathrm{g} \mathrm{mL}^{-1}$; moderate to MIC between 100 and $500 \mu \mathrm{g} \mathrm{mL}^{-1}$; weak for MIC between 500 and $1000 \mu \mathrm{g} \mathrm{mL}^{-1}$ and inactive if MIC $>1000 \mu \mathrm{g} \mathrm{mL}{ }^{-1} .41$
After MIC determination, the minimal bactericidal or fungicidal concentration (MBC and MFC), was also carried out by subculture technique in Mueller Hinton agar and Sabouraud agar for bacteria and yeasts, respectively. For this, $10 \mu \mathrm{L}$ was removed from each well where there was growth inhibition and a positive control and transferred to the agar incubating at $37^{\circ} \mathrm{C}$ for an additional $24 \mathrm{~h}$.

\section{Broth microdilution assay for dermatophytes}

The dermatophyte strains Trichophyton rubrum ATCC 28189, Trichophyton mentagrophytes ATCC 11480, and Microsporum gypseum ATCC 14683 were used in this study. They were cultured at $28^{\circ} \mathrm{C}$ on Sabouraud dextrose agar tubes for 20 days before experiments. Spores were collected in sterile saline and suspensions were adjusted to $1.0 \times 10^{5}$ spores $\mathrm{mL}^{-1}$.

The minimum inhibitory concentrations (MIC) of all samples were determined by microdilution techniques in RPMI medium, described by the Clinical and Laboratory Standards Institute (CLSI) ${ }^{44}$ One hundred microliters of the medium were added to each well of a 96-well plate and a volume of $100 \mu \mathrm{L}$ of the test solution was added to the wells in the first row, and then a serial dilution was performed. Then, $5 \mu \mathrm{L}$ inoculum $\left(10^{5}\right.$ spores $\left.\mathrm{mL}^{-1}\right)$ were added to wells. Microplates were incubated at $28^{\circ} \mathrm{C}$, and the MICs were recorded after $72 \mathrm{~h}$ for yeast of incubation. The MIC was defined as the lowest concentration which resulted in the inhibition of visual growth. Minimal fungicidal concentrations (MFC) were determined by subculturing $10 \mu \mathrm{L}$ of the culture from each negative well and from the positive control in Sabouraud dextrose agar.

\section{Supplementary Information}

Supplementary information $\left({ }^{1} \mathrm{H}\right.$ NMR, ${ }^{13} \mathrm{C}$ NMR, GC-MS, and FTIR of the synthesized compounds) is available free of charge at http://jbcs.sbq.org.br as PDF file.

\section{Acknowledgments}

The authors thank the National Council for Scientific and Technological Development (CNPq, Brazil), and the Coordination for the Improvement of Higher Level Personnel (CAPES, Brazil) for financial support and fellowships of F. G. Borges, T. Zugman, P. T. Bandeira, M. C. Dalmolin, D. B. Scariot, and F. P. Garcia.

\section{Author Contributions}

The synthesis and structural characterizations of orgacochalcogenated compounds were performed by F. G. 
Borges, T. Zugman, P. T. Bandeira, and M. C. Dalmolin, supervised by Prof L. Piovan and A. R. M. de Oliveira. Biological assays were carried out by D. B. Scariot and F. P. Garcia, under Prof C. V. Nakamura's supervision. F. G. Borges, T. Zugman, F. P. Garcia, and L. Piovan wrote the manuscript. L. Piovan, A. R. M. de Oliveira and C.V. Nakamura contributed with the laboratories and financial structure for the development of the experiments.

\section{References}

1. Victoria, F. N.; Radatz, C. S.; Sachini, M.; Jacob, R. G.; Alves, D.; Savegnago, L.; Perin, G.; Motta, A. S.; da Silva, W. P.; Lenardão, E. J.; Food Control 2012, 23, 95.

2. Victoria, F. N.; Radatz, C. S.; Sachini, M.; Jacob, R. G.; Perin, G.; da Silva, W. P.; Lenardão, E. J.; Tetrahedron Lett. 2009, 50, 6761 .

3. Guil-Guerrero, J. L.; Ramo, L.; Moreno, C.; Zúñiga-Paredes, J. C.; Carlosama-Yepez, M.; Ruales, P.; Livest. Sci. 2016, 189, 32.

4. Balouiri, M.; Sadiki, M.; Ibnsouda, S. K.; J. Pharm. Anal. 2016 , 71.

5. da Silva, C. M.; da Silva, D. L.; Modolo, L. V.; Alves, R. B.; de Resende, M. A.; Martins, C. V. B.; de Fátima, A.; J. Adv. Res. 2011, 2, 1; Tahlan, S.; Ramasamy, K.; Lim, S. M.; Shah, S. A. A.; Mani, V.; Narasimhan, B.; BMC Chem. 2019, 13, 1.

6. Morsy, M. A.; Ali, E. M.; Kandeel, M.; Venugopala, K. N.; Nair, A. B.; Greish, K.; El-Daly, M.; Antibiotics 2020, 9, 221.

7. Blair, J. M. A.; Webber, M. A.; Baylay, A. J.; Ogbolu, D. O.; Piddock, L. J. V.; Nat. Rev. Microbiol. 2015, 13, 42; Patil, M.; Poyil, A. N.; Joshi, S. D.; Patil, S. A.; Patil, S. A.; Bugarin, A.; Bioorg. Chem. 2019, 92, 103217.

8. Xu, Z.-K.; Flavin, M. T.; Flavin, J.; Expert Opin. Invest. Drugs 2014, 23, 163.

9. Taubes, G.; Science 2008, 321, 356.

10. Malanovic, N.; Lohner, K.; Pharmaceuticals 2016, 9, 59.

11. de Oliveira, D. M. P.; Forde, B. M.; Kidd, T. J.; Harris, P. N. A.; Schembri, M. A.; Beatson, S. A.; Paterson, D. L.; Walker, M. J.; Clin. Microbiol. Rev. 2020, 33, e00181-19.

12. Bucknell, D. G.; Gasser, R. B.; Irving, A.; Whithear, K.; Aust. Vet. J. 1997, 75, 355; Torres, A. G.; Pathog. Dis. 2017, 75, $\mathrm{ftx} 012$.

13. Li, B.; Wang, K.; Zhang, R.; Li, B.; Shen, Y.; Ji, Q.; Eur. J. Med. Chem. 2019, 182, 111669; Brown, G. D.; Denning, D. W.; Gow, N. A. R.; Levitz, S. M.; Netea, M. G.; White, T. C.; Med. Mycol. 2012, 4, 165rv13.

14. Marc, G.; Stana, A.; Pîrnau, A.; Vlase, L.; Vodnar, D. C.; Duma, M.; Tiperciuc, B.; Oniga, O.; SLAS Discovery 2018, 23, 807.

15. Pinto, S. M. L.; Rivera, Y.; Sandoval, L. V. H.; Lizarazo, J. C.; Rincón, J. J.; Méndez, L. Y. V.; J. Med. Microbiol. 2019, 68, 1109 .
16. Silva, N. C. C.; Júnior, A. F.; J. Venomous Anim. Toxins Incl. Trop. Dis. 2010, 16, 402.

17. Tsemeugne, J.; Fondjo, E. S.; Tamokou, J.-D.; Rohand, T.; Ngongang, A. D.; Kuiate, J. R.; Sondengam, B. L.; Int. J. Med. Chem. 2018, 2018, 9197821.

18. Bueno, D. C.; Meinerz, D. F.; Allebrandt, J.; Waczuk, E. P.; dos Santos, D. B.; Mariano, D. O. C.; Rocha, J. B. T.; BioMed Res. Int. 2013, 2013, ID 537279; Rossato, J. I.; Ketzer, L. A.; Centuriao, F. B.; Silva, S. J. N.; Ludtke, D. S.; Zeni, G.; Braga, A. L.; Rubin, M. A.; Rocha, J. B. T.; Neurochem. Res. 2002, 27, 297; Meotti, F. C.; Stangherlin, E. C.; Zeni, G.; Nogueira, C. W.; Rocha, J. B. T.; Environ. Res. 2004, 94, 276; Bandeira, P. T.; Dalmolin, M. C.; Oliveira, M. M.; Nunes, K. C.; Garcia, F. P.; Nakamura, C. V.; de Oliveira, A. R. M.; Piovan, L.; Bioorg. Med. Chem. 2019, 27, 410; Reich, H. J.; Hondal, R. J.; ACS Chem. Biol. 2016, 11, 821; Ibrahim, M.; Muhammad, N.; Naeem, M.; Deobald, A. M.; Kamdem, J. P.; Rocha, J. B. T.; Toxicol. In Vitro 2015, 29, 947; Tanini, D.; Panzella, L.; Amorati, R.; Capperucci, A.; Pizzo, E.; Napolitano, A.; Menichetti, S.; d'Schia, M.; Org. Biomol. Chem. 2015, 13, 5757; Arai, K.; Kumakura, F.; Takahira, M.; Sekiyama, N.; Kuroda, N.; Suzuki, T.; Iwaoka, M.; J. Org. Chem. 2015, 80, 5633; Ibrahim, M.; Hassan, W.; Anwar, J.; Deobald, A. M.; Kamdem, J. P.; Souza, D. O.; Rocha, J. B. T.; Toxicol. In Vitro 2014, 28, 524; Alberto, E. E.; do Nascimento, V.; Braga, A. L.; J. Braz. Chem. Soc. 2010, 21, 2032.

19. Wang, L.; Yang, Z.; Fu, J.; Yin, H.; Xiong, K.; Tan, Q.; Jin, H.; Li, J.; Wang, T.; Tang, W.; Yin, J.; Cai, G.; Liu, M.; Kehr, S.; Becker, K.; Zeng, H.; Free Radicals Biol. Med. 2012, 52, 898; Doering, M.; Ba, L. A.; Lilienthal, N.; Nicco, C.; Scherer, C.; Abbas, M.; Zada, A. A. P.; Coriat, R.; Burkholz, T.; Wessjohann, L.; Diederich, M.; Batteux, F.; Herling, M.; Jacob, C.; J. Med. Chem. 2010, 53, 6954; Seng, H.-L.; Tiekink, E. R. T.; Appl. Organomet. Chem. 2012, 26, 655; Paschoalin, T.; Martens, A. A.; Omori, Á. T.; Pereira, F. V.; Juliano, L.; Travassos, L. R.; Machado-Santelli, G. M.; Cunha, R. L. O. R.; Bioorg. Med. Chem. 2019, 27, 2537; Gandin, V.; Khalkar, P.; Braude, J.; Fernandes, A. P.; Free Radicals Biol. Med. 2018, 127, 80; Garnica, P.; Encío, I.; Plano, D.; Palop, J. A.; Sanmartín, C.; ACS Med. Chem. Lett. 2018, 9, 306; Silberman, A.; Kalechman, Y.; Hirsch, S.; Erlich, Z.; Sredni, B.; Albeck, A.; ChemBioChem 2016, 17, 918; Arsenyan, P.; Paegle, E.; Domracheva, I.; Gulbe, A.; Kanepe-Lapsa, I.; Shestakova, I.; J. Med. Chem. 2014, 87, 471; Du, P.; Saidu, N. E. B.; Intemann, J.; Jacob, C.; Montenarh, M.; Biochim. Biophys. Acta 2014, 1840, 1808; Sredni, B.; Semin. Cancer Biol. 2012, 22, 60; Fernandes, A. P.; Gandin, V.; Biochim. Biophys. Acta 2015, 1850, 1642.

20. Cunha, R. L. O. R.; Urano, M. E.; Chagas, J. R.; Almeida, P. C.; Bincoletto, C.; Tersariol, I. L. S.; Comasseto, J. V.; Bioorg. Med. Chem. Lett. 2005, 15, 755; Maluf, S. E. C.; Melo, P. M. S.; Varotti, F. P.; Gazarini, M. L.; Cunha, R. L. O. R.; Carmona, A. 
K.; Parasitol. Int. 2016, 65, 20; Cunha, R. L. O. R.; Gouvea, I E.; Feitosa, G. P. V.; Alves, M. F. M.; Bromme, D.; Comasseto, J. V.; Tersariol, I. L. S.; Juliano, L.; Biol. Chem. 2009, 390, 1205; Caracelli, I.; Veja-Teijido, M.; Zukerman-Schpector, J.; Cezari, M. H. S.; Lopes, J. G. S.; Juliano, L.; Santos, P. S.; Comasseto, J. V.; Cunha, R. L. O. R.; Tiekink, E. R. T.; J. Mol. Struct. 2012, 1013, 11; Piovan, L.; Alves, M. F. M.; Juliano, L.; Brömme, D.; Cunha, R. L. O. R.; Andrade, L. H.; Bioorg. Med. Chem. 2011, 19, 2009; Piovan, L.; Alves, M. F. M.; Juliano, L.; Brömme, D.; Cunha, R. L. O. R.; Andrade, L. H.; J. Braz. Chem. Soc. 2010, 21, 2108.

21. Piovan, L.; Milani, P.; Silva, M. S.; Moraes, P. G.; Demasi, M.; Andrade, L. H.; Eur. J. Med. Chem. 2014, 73, 280.

22. Abdo, M.; Liu, S.; Zhou, B.; Walls, C. D.; Wu, L.; Knapp, S.; Zhang, Z.-Y.; J. Am. Chem. Soc. 2008, 130, 13196; Brondani, P. B.; Guilmoto, N. M. A. F.; Dudek, H. M.; Fraaije, M. W.; Andrade, L. H.; Tetrahedron 2012, 68, 10431; Piovan, L.; Wu, L.; Zhang, Z.-Y.; Andrade, L. H.; Org. Biomol. Chem. 2011, 9, 1347.

23. Gai, B. M.; Stein, A. L.; Roehrs, J. A.; Bilheri, F. N.; Nogueira, C. W.; Zeni, G.; Org. Biomol. Chem. 2012, 10, 798; Sampaio, T. B.; Bilheri, F. N.; Zeni, G. R.; Nogueira, C. W.; Behav. Brain Res. 2020, 386, ID 32184159; Savegnago, L.; Jesse, C. R.; Pinto, L. G.; Rocha, J. B. T.; Barancelli, D. A.; Nogueira, C. W.; Zeni, G.; Pharmacol., Biochem. Behav. 2008, 88, 418; da Rocha, J. T.; Gai, B. M.; Pinton, S.; Sampaio, T. B.; Nogueira, C. W.; Zeni, G.; Psychopharmacology 2012, 222, 709.

24. de Freitas, A. S.; Rocha, J. B. T.; Neurosci. Lett. 2011, 503, 1; Pinton, S.; da Rocha, J. T.; Zeni, G.; Nogueira, C. W.; Neurosci. Lett. 2010, 472, 56; Ávila, D. S.; Colle, D.; Gubert, P.; Palma, A. S.; Puntel, G.; Manarin, F.; Noremberg, S.; Nascimento, P. C.; Aschner, M.; Rocha, J. B. T.; Soares, F. A. A.; Toxicol. Sci. 2010, 115, 194; Okun, E.; Arumugam, T. V.; Tang, S.-C.; Gleichmann, M.; Albeck, M.; Sredni, B.; Mattson, M. P.; J. Neurochem. 2007, 102,1232

25. Gouvea, I. E.; Santos, J. A. N.; Burlandy, F. M.; Tersariol, I. L. S.; da Silva, E. E.; Juliano, M. A.; Juliano, L.; Cunha, R. L. O. R.; Biol. Chem. 2011, 392, 587; Giurg, M.; Golab, A.; Suchodolski, J.; Kaleta, R.; Krasowska, A.; Piasecki, E.; PietkaOttlik, M.; Molecules 2017, 22, 974; Wójtowicz, H.; Chojnacka, M.; Młochowski, J.; Palus, J.; Syper, L.; Hudecova, D.; Uher, M.; Piasecki, E.; Rybka, M.; Il Farmaco 2003, 58, 1235; Sartori, G.; Jardim, N. S.; Sari, M. H. M.; Dobrachinski, F.; Pesarico, A. P.; Rodrigues Jr., L. C.; Cargnelutti, J.; Flores, E. F.; Prigol, M.; Nogueira, C. W.; J. Cell. Biochem. 2016, 117, 1638; Sancineto, L.; Mariotti, A.; Bagnoli, L.; Marini, F.; Desantis, J.; Iraci, N.; Santi, C.; Pannecouque, C.; Tabarrini, O.; J. Med. Chem. 2015, 58, 9601; Pietka-Ottlik, M.; Wójtowicz-Mlochowska, H.; Kolodziejczyk, K.; Piasecki, E.; Mlochowski, J.; Chem. Pharm. Bull. 2008, 56, 1423; Sahu, P. K.; Kim, G.; Yu, J.; Ahn, J. Y.; Choi, Y.; Jin, X.; Kim, J.-H.; Lee, S. K.; Park, S.; Jeong, L. S.; Org. Lett. 2014, 16, 5796; Sahu, P. K.; Umme, T.; Yu, J.;
Nayak, A.; Kim, G.; Noh, M.; Lee, J.-Y.; Kim, D.-D.; Jeong, L. S.; J. Med. Chem. 2015, 58, 8734.

26. Nogueira, C. W.; Quinhones, E. B.; Junhg, E. A. C.; Zeni, G.; Rocha, J. B. T.; Inflammation Res. 2003, 52, 56; Jesse, C. R.; Savegnago, L.; Nogueira, C. W.; J. Pharm. Pharmacol. 2009, 61, 623; Chagas, P. M.; Rosa, S. G.; Sari, M. H. M.; Oliveira, C. E. S.; Canto, R. F. S.; da Luz, S. C. A.; Braga, A. L.; Nogueira, C. W.; Pharmacol., Biochem. Behav. 2014, 118, 87; Pinz, M.; Reis, A. S.; Duarte, V.; da Rocha, M. J.; Goldani, B. S.; Alves, D.; Savegnago, L.; Luchese, C.; Wilhelm, E. A.; Eur. J. Pharmacol. 2016, 780, 122.

27. Okoronkwo, A. E.; Rosário, A. R.; Alves, D.; Savegnago, L.; Nogueira, C. W.; Zeni, G.; Tetrahedron Lett. 2008, 49, 3252; Wilhelm, E. A.; Jesse, C. R.; Bortolatto, C. F.; Nogueira, C. W.; Savegnago, L.; Pharmacol., Biochem. Behav. 2009, 93, 419.

28. Wilhelm, E. A.; Gai, B. M.; Souza, A. C. G.; Bortolatto, C. F.; Roehrs, J. A.; Nogueira, C. W.; Mol. Cell. Biochem. 2012, 365, 175.

29. Brodsky, M.; Halpert, G.; Albeck, M.; Sredni, B.; J. Inflammation 2010, 7, 3; Duntas, L. H.; Horm. Metab. Res. 2009, 41, 443; Martínez-Ramos, F.; Salgado-Zamora, H.; Campos-Aldrete, M. E.; Melendez-Camargo, E.; Márquez-Flores, Y.; SorianoGarcía, M.; Eur. J. Med. Chem. 2008, 43, 1432.

30. Ferraz, M. C.; Mano, R. A.; Oliveira, D. H.; Maia, D. S. V.; Silva, W. P.; Savegnago, L.; Lenardão, E. J.; Jacob, R. G.; Medicines 2017, 4, 39.

31. Sharma, N.; Kumar, S.; Maurya, I. K.; Bhasin, K. K.; Verma, A.; Wangoo, N.; Bhasin, A. K. K.; Mehta, S. K.; Kumar, S.; Sharma, R. K.; RSC Adv. 2016, 6, 114224.

32. Kumar, S.; Sharma, N.; Maurya, I. K.; Bhasin, A. K.; Wangoo, N.; Brandão, P.; Félix, V.; Bhasin, K. K.; Sharma, R. K.; Eur. J. Med. Chem. 2016, 123, 916.

33. Bugarčić, Z. M.; Divac, V. M.; Kostić, M. D.; Janković, N. Ž.; Heinemann, F. W.; Radulović, N. S.; Stojanović-Radić, Z. Z.; J. Inorg. Biochem. 2015, 143, 9.

34. Abdel-Hafez, Sh. H.; Russ. J. Bioorg. Chem. 2010, 36, 370.

35. Vargas, J.; Narayanaperumal, S.; Gul, K.; Ravanello, B. B.; Dornelles, L.; Soares, L. C.; Alves, C. F. S.; Schneider, T.; Vaucher, R. A.; Santos, R. C. V.; Rodrigues, O. E. D.; Tetrahedron 2012, 68, 10444

36. Abdel-Hafez, Sh. H.; Anthonsen, H. W.; Sliwka, H.-R.; Partali, V.; Phosphorus, Sulfur Silicon Relat. Elem. 2005, 180, 2217.

37. Al-Masoudi, W. A.; Al-Asadi, R. H.; Othman, R. M.; Al-Masoudi, N. A.; Eur. J. Chem. 2015, 6, 374.

38. Pinheiro, F. C.; Bortolotto, V. C.; Araujo, S. M.; Poetini, M. R.; Sehn, C. P.; Neto, J. S. S.; Zeni, G.; Prigol, M.; J. Microbiol. Biotechnol. 2018, 28, 1209.

39. de Sá, L. F. R.; Toledo, F. T.; Gonçalves, A. C.; Sousa, B. A.; dos Santos, A. A.; Brasil, P. F.; da Silva, V. A. D.; Tessis, A. C.; Ramos, J. A.; Carvalho, M. A.; Lamping, E.; Ferreira-Pereira, A.; Antimicrob. Agents Chemother. 2017, 61, 1. 
40. Dalmolin, M. C.; Bandeira, P. T.; Ferri, M. S.; Oliveira, A. R. M.; Piovan, L.; J. Organomet. Chem. 2018, 874, 32.

41. Holetz, F. B.; Pessini, G. L.; Sanches, N. R.; Cortez, D. A.; Nakamura, C. V.; Mem. Inst. Oswaldo Cruz 2002, 97, 1027.

42. Clinical and Laboratory Standards Institute (CLSI); M07-A10 Methods for Dilution Antimicrobial Susceptibility Test for Bacteria that Grow Aerobically, Approved Standard, $10^{\text {th }}$ ed.; CLSI: Wayne, USA, 2015, available at https://clsi.org/ media/1632/m07a10_sample.pdf, accessed in October 2020.

43. Clinical and Laboratory Standards Institute (CLSI); M27-A3 Reference Method for Broth Dilution Antifungal Susceptibility
Testing of Yeasts, Approved Standard, $3^{\text {rd }}$ ed.; CLSI: Wayne, USA, 2008, available at https://clsi.org/media/1461/m27a3_ sample.pdf, accessed in October 2020.

44. Clinical and Laboratory Standards Institute (CLSI); M38-A2 Reference Method for Broth Dilution Antifungals Susceptibility Testing of Conidium-Forming Filamentous Fungi, Approved Standard, $2^{\text {nd }}$ ed.; CLSI: Wayne, USA, 2008, available at https:// clsi.org/media/1455/m38a2_sample.pdf, accessed in October 2020 .

Submitted: July 12, 2020

Published online: October 8, 2020 